\title{
Liver transplantation for bile duct injury after cholecystectomy
}

\author{
José Francisco Rêgo e SILVA FILHO, Gustavo Rêgo COELHO, José Alberto Dias LEITE FILHO, \\ Paulo Everton Garcia COSTA, Marcos Aurelio Pessoa BARROS and José Huygens Parente GARCIA
}

\begin{abstract}
Background - Bile duct injury is a life-threatening complication that requires proper management to prevent the onset of negative outcomes. Patients may experience repeated episodes of cholangitis, secondary biliary cirrhosis, end-stage liver disease and death. Objective - To report a single center experience in iatrogenic secondary liver transplantation after cholecystectomy and review the literature. Methods - This was a retrospective single center study. Of the 1662 liver transplantation realized, $10(0.60 \%)$ were secondary to iatrogenic bile ducts injuries due cholecystectomies. Medical records of these patients were reviewed in this study. Results - Nine of 10 patients were women; the median time in waiting list and between cholecystectomy and inclusion in waiting list was of 222 days and of 139.9 months, respectively. Cholecystectomy was performed by open approach in eight $(80 \%)$ cases and by laparoscopic approach in two $(20 \%)$ cases. The patients underwent an average of 3.5 surgeries and procedures before liver transplantation. Biliary reconstruction was realized with a Roux-en-Y hepaticojejunostomy in nine (90\%) cases. Mean operative time was 447.2 minutes and the median red blood cell transfusion was 3.4 units per patient. Mortality in the first month was of $30 \%$. Conclusion - Although the liver transplantation is an extreme treatment for an initially benign disease, it has its well-defined indications in treatment of bile duct injuries after cholecystectomy, either in acute or chronic scenario.
\end{abstract}

HEADINGS - Liver transplantation. Cholecystectomy. Bile ducts. Biliary liver cirrhosis.

\section{INTRODUCTION}

The greatest source of postoperative biliary injuries is cholecystectomy, whether open or laparoscopic. The incidence in open cholecystectomy ranges between $0.2 \%$ and $0.3 \%$, and in laparoscopic approach the incidence range between $0.3 \%$ and $0.6 \%{ }^{(1)}$. Bile duct injuries is a life-threatening complication that require proper management to prevent the onset of negative outcomes ${ }^{(2)}$. The two most common factors related with these injuries are cholecystitis and misperception or inexperience of the surgeon ${ }^{(1)}$. Patients may experience repeated episodes of cholangitis, secondary biliary cirrhosis, end-stage liver disease and death ${ }^{(3)}$.

Successful management of these patients requires careful planning. Treatment options include endoscopic retrograde cholangiopancreatography (ERCP), percutaneous biliary intervention, biliary reconstruction, hepatic resection and liver transplantation ${ }^{(1)}$. Some factors that could negatively influence post-operative outcomes in repair surgery are the delay in correct diagnoses, the elapsed period between the time of bile duct injury and referral and the repair in specialized center (associated with higher success hates) ${ }^{(4)}$.

Liver transplantation can be performed acutely for iatrogenic biliary injury when it is associated with major vascular lesions and the patients presents with acute liver failure. It can also be done for patients who develop portal hypertension or secondary biliary cirrhosis (SBC) as a result of longstanding biliary obstruction ${ }^{(1)}$.

\section{METHODS}

This was a retrospective single center study. Between January 2002 and December 2018, 1662 liver transplantations were performed by our team in a tertiary hospital in Northeast of Brazil. Of this, $12(0.72 \%)$ liver transplantations had the indication for secondary biliary cirrhosis (SBC) and $10(0.60 \%)$ of them secondary to iatrogenic bile ducts injuries due cholecystectomies.

After the study was approved by the Ethics Committee of our Institution, medical records of the 10 patients undergoing liver transplantation for bile duct injury after cholecystectomy were reviewed in this study. Analyzed data included gender, age, type of initial surgery, time of diagnosis, number of previous surgeries before liver transplantation (including endoscopic and/or radiological procedures), indication for liver transplantation, time in waiting list, model for end-stage liver disease (MELD) score at the time of transplantation and course and outcome of liver transplantation. Data were compared with those of other transplants performed in the same institution previously published.

\section{RESULTS}

Between January 2002 and December 2018, 1662 liver transplantations were performed in our service. Of these, $12(0.72 \%)$ liver transplantations had the indication for secondary biliary cir- 
rhosis (SBC) and $10(0.60 \%)$ of them secondary to iatrogenic bile ducts injuries due cholecystectomies. Nine patients were women, and the median time in waiting list was of 222 days. Patients were listed for transplantation between 4 and 33 years after the initial surgery with a median time between cholecystectomy and inclusion in waiting list of 139.9 months.

Cholecystectomy was performed by open approach in eight $(80 \%)$ cases and by laparoscopic approach in two $(20 \%)$ cases, and in one case the operation was converted to open procedure due the identification of the iatrogenic bile duct injury. The patients underwent an average of 3.5 surgeries and procedures (range: 2-8) related to this complication before liver transplantation. None of the patients underwent primary surgical repair in our service, having been referenced only after the development of cirrhosis. The mean MELD score at the time of liver transplantation was 19.1, ranging from 10 to 25 (TABLE 1).

The indication of liver transplantation was SBC in all ten patients. Liver transplantation was realized with a full-size deceased donor graft with the piggyback technique in all cases. Biliary reconstruction was realized with a Roux-en-Y hepaticojejunostomy in nine cases $(90 \%)$ and a duct-to-duct anastomosis in one case $(10 \%)$.
Mean operative time was 447.2 minutes, ranging from 300 to 585 minutes. The median red blood cell transfusion was 3.4 units per patient (range: $0-8$ ) and the median use of fresh frozen plasma was 2.22 units. We use an autologous blood recovery system (Cell Saver) in five of the patients. In one patient, medical record of these data above were not possible to be recovered.

Three patients died within 30 days of liver transplantation, all in the first post-operative day, in one of those the cause was primary non-function of the graft and in the others were bleeding due to postoperative coagulation disorder. The median hospital stay for the others seven patients was 13.4 days (range: 7-21).

The diagnosis of cirrhosis was confirmed by pathological examination of the explanted organs. In one case, there was a $2 \mathrm{~mm}$ diameter hepatocellular carcinoma.

\section{DISCUSSION}

The leading cause of iatrogenic bile duct injury is still cholecystectomy, despite being one infrequent complication of this surgery, which can be explained by the high number of realized procedures ${ }^{(1)}$. The laparoscopic approach specially at the beginning

TABLE 1. Characteristics, treatment and outcome of patients with bile duct injury after laparoscopic and open cholecystectomy.

Patient 1 Patient 2 Patient 3 Patient 4 Patient 5 Patient 6 Patient 7 Patient 8 Patient 9 Patient 10

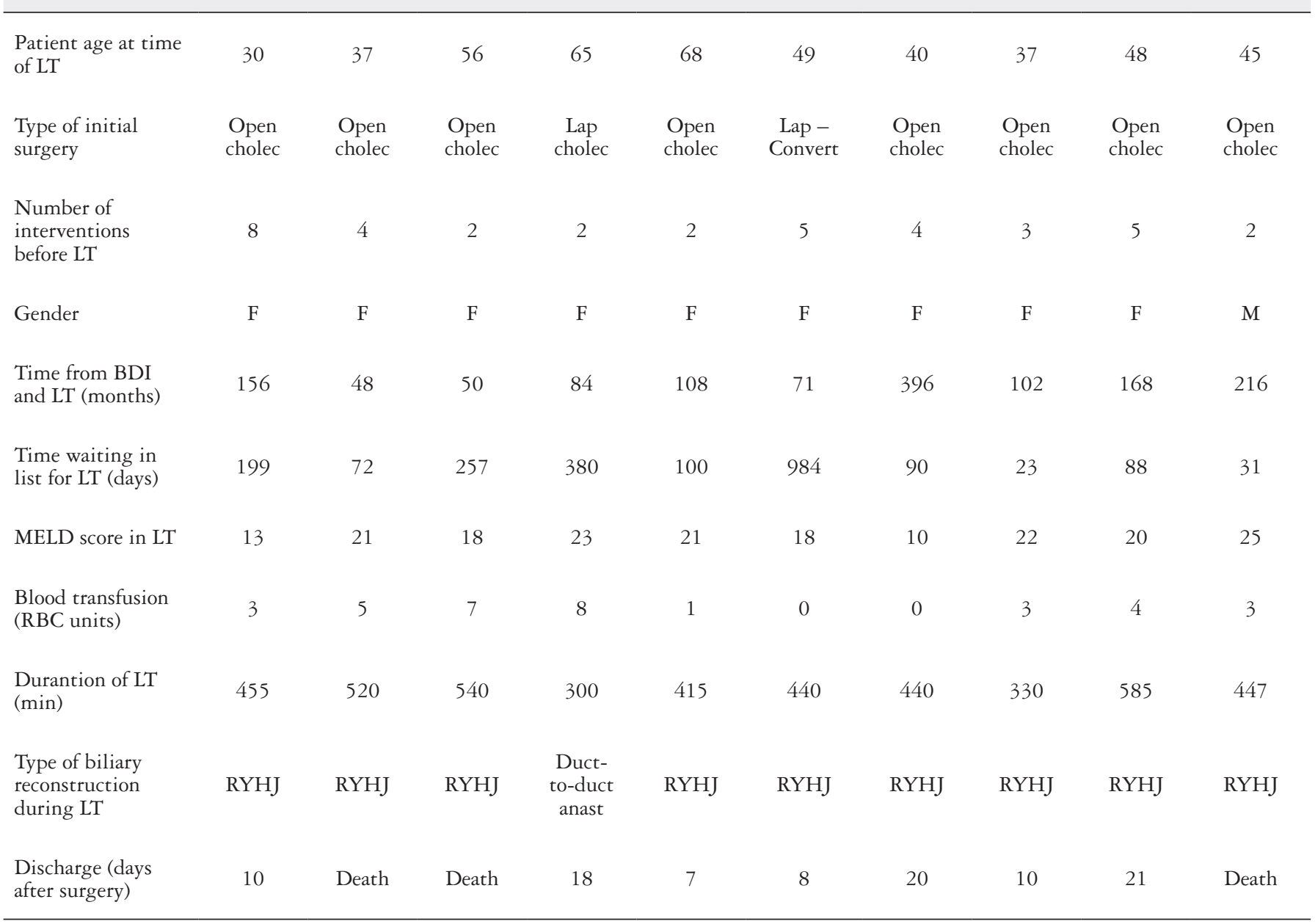

LT: liver transplantation; MELD: model for end-stage liver disease; RBC: red blood cell; RYHJ: Roux-en-Y hepaticojejunostomy. 
of its use was associated with an increase in the incidence of bile duct injuries, however there has been a decline in this lesions as surgeons gained more experience with laparoscopic surgery ${ }^{(5)}$. The incidence in laparoscopic cholecystectomy range between $0.3 \%$ and $0.6 \%$, which is similar to open approach, where it ranges between $0.2 \%$ and $0.3 \%{ }^{(1)}$.

The bile duct injury is one of the most serious complications of cholecystectomy and patients may develop recurrent pyogenic cholangitis, secondary biliary cirrhosis, end-stage liver disease and even death $^{(2,3)}$. Correct initial management is essential and requires careful planning, ideally with a multidisciplinary team with experience in complex hepatobiliary surgery. Some factors that could negatively influence post-operative outcomes in repair surgery are the delay in correct diagnoses, coexistence of vascular injury, presence of biliary peritonitis at the time of repair, level injury at or above the biliary confluence, the elapsed period between the time of bile duct injury and referral and the repair in specialized center (associated with higher success hates) ${ }^{(2,4)}$. Before any intervention, the type and extent of biliary injury must be completely defined, usually with imaging tests. Treatment options include endoscopic retrograde cholangiopancreatography (ERCP), percutaneous biliary intervention, biliary reconstruction, hepatic resection and liver transplantation ${ }^{(1,4)}$.

Liver transplantation is an exception treatment and is realized in a rate of $0.8 \%$ in iatrogenic bile duct injuries after cholecystectomy ${ }^{(6)}$. It can be performed in two main situations in the bile duct injury: in an acute scenario and in a chronic scenario. It can be done in acute liver failure, due to massive liver necrosis, which is usually secondary to a devastating combined vascular (hepatic artery and portal vein) and biliary injury. Although liver transplantation is rarely successful in these cases, mainly because of the severe clinic conditions and septic complications, it can be the only treatment option ${ }^{(1,2,4)}$.

The most common indication for liver transplantation for this patients occurs in a chronic scenario, after the progression to secondary biliary cirrhosis with associated liver failure, with or without portal hypertension ${ }^{(1,4,7,8)}$. Negi et al. have shown that the average interval at witch biliary obstruction results in periportal fibrosis, severe fibrosis and cirrhosis was 4, 22 and 62months, respectively ${ }^{(9)}$. The transplantation on this occasion has a greater technical complexity, when compared with the transplants for other causes, since patients commonly underwent multiple complex surgical procedures in the past. Therefore, many adhesions should be expected in these cases, which, when combined with the presence of portal hypertension, increase surgical time and bleeding even when transplant is performed by experienced surgeons. This may be evidenced by longer surgical times, greater use of blood products and increased perioperative mortality when compared with transplantations due to cirrhosis of other etiologies. Their prognosis, however, is similar to that of patients transplanted for other indications after they pass post-operative period ${ }^{(2,4,6,10)}$.

Ardiles et al. analyzed their experience using liver transplantation as a definitive treatment for bile duct injuries, and although there was no intraoperative mortality, four patients died during the first month after liver transplantation, and another four died in the late postoperative period. The authors reported a higher rate of major post-operative complications (52\%) in the secondary biliary cirrhosis group, according to the Clavien classification, compared with other etiologies ${ }^{(4)}$. Addeo et al. ${ }^{(11)}$ reported that the mortality rate for this indication was as high as $61 \%$, and half of the patients died in the immediate post-operative period. This showed that liver transplantation for bile duct injuries is associated with high mortality and morbidity rates. The mortality rate approached $35 \%$, and the morbidity ranged from $60 \%$ to $100 \%{ }^{(11)}$. Comparing the patients submitted to liver transplantation for SBC with all other causes of hepatic insufficiency in our service, we can find out that the use of red blood cell transfusion $(3.44$ versus 1.01), cell saver (used in 55.55\% versus $46.4 \%$ ) and fresh frozen plasma transfusion (2.22 versus 1.01$)$ was higher in the first group (TABLE 2) ${ }^{(12)}$.

TABLE 2. Characteristics of blood products.

\begin{tabular}{lcc}
\hline Units & SCB & All causes transplants \\
\hline RBC & 3.44 & 1.01 \\
Cell saver & $55.55 \%$ & $46.4 \%$ \\
FFP & 2.22 & 1.01 \\
\hline
\end{tabular}

RBC: red blood cell; FFP: fresh frozen plasma; SCB: secondary biliary cirrhosis.

To the best of our knowledge, this is one of the largest single center series of transplanted patients for bile duct injury after cholecystectomy. In our casuistry, none of the patients was transplanted in an acute scenario for acute liver failure. We noticed that, contrary to what has been observed in other series, most of our patients (approximately 80\%) were initially submitted to an open cholecystectomy. One possible explanation is the fact that we are in a poor country, where laparoscopy surgery is not easily available and is realized mainly in reference centers, which house the most experienced surgeons.

Another disparity in our series was the average interval of approximately 140 months between bile duct lesion and transplantation, which can be explained by the poor condition of the public health system, which leads the patient to be referenced only later.

\section{CONCLUSION}

Although the liver transplantation is an extreme treatment for an initial benign disease, it has its well-defined indications in treatment of bile duct injuries after cholecystectomy, either in acute or chronic scenario. Referencing such patients for advanced hepatobiliary surgery and liver transplantation centers should not be delayed, since treatment may provide long-term survival and good quality of life.

\section{Authors' contribution}

Silva Filho JFR: drafting of the manuscript and submit the manuscript. Coelho GR: analysis and data interpretation. Leite Filho JAD: data acquisition. Costa PEG: critical revision. Barros MAP: Critical revision. Garcia JHP: study conception and design.

\section{Orcid}

José Francisco Rêgo e Silva Filho. Orcid: 0000-0001-8474-5031. Gustavo Rêgo Coelho. Orcid: 0000-0003-0845-2864.

José Alberto Dias Leite Filho. Orcid: 0000-0002-8729-7235.

Paulo Everton Garcia Costa. Orcid: 0000-0001-6589-1957.

Marcos Aurelio Pessoa Barros. Orcid: 0000-0001-7424-2449.

José Huygens Parente Garcia. Orcid: 0000-0003-4401-137X. 
Silva Filho JFR, Coelho GR, Leite Filho JAD, Costa PEG, Barros MAP, Garcia JHP. Transplante de fígado para tratamento de lesão de via biliar após colecistectomia. Arq Gastroenterol. 2019;56(3):300-3.

RESUMO - Contexto - A lesão da via biliar é uma complicação que pode ameaçar a vida e que requer manejo adequado para prevenir o aparecimento de desfechos negativos. Os pacientes podem apresentar episódios repetidos de colangite, cirrose biliar secundária, doença hepática terminal e até mesmo morte. Objetivo - Avaliar a experiência de um único centro em transplante hepático secundário a lesão iatrogênica de via biliar pós-colecistectomia e fazer uma revisão de literatura. Métodos - Este foi um estudo retrospectivo de um único centro. Dos 1662 transplantes de fígado, 10 ( $0,60 \%)$ foram secundários a lesões iatrogênicas das vias biliares devido à colecistectomias. Os prontuários médicos desses pacientes foram revisados neste estudo. Resultados - Nove dos dez pacientes eram mulheres; o tempo médio em lista de espera de transplante e entre colecistectomia e inclusão na lista de espera foi de 222 dias e de 139,9 meses, respectivamente. A colecistectomia foi realizada por abordagem aberta em oito ( $80 \%$ ) casos e por abordagem laparoscópica em dois (20\%) casos. Os pacientes foram submetidos a uma média de 3,5 cirurgias e procedimentos antes do transplante de fígado e a reconstrução biliar foi realizada com hepaticojejunostomia em Y-de-Roux em nove ( $90 \%$ ) casos. O tempo operatório médio foi de 447,2 minutos e a média de transfusão de concentrados de hemácias foi de 3,4 unidades por paciente. Mortalidade no primeiro mês foi de $30 \%$. Conclusão - Embora o transplante de fígado seja um tratamento extremo para uma doença inicialmente benigna, ele tem suas indicações bem definidas no tratamento de lesões biliares após colecistectomia, seja em um cenário agudo ou crônico.

DESCRITORES - Transplante de fígado. Colecistectomia. Ductos biliares. Cirrose hepática biliar.

\section{REFERENCES}

1. Corvera CU, Alemi F, Jarnagin WR. Benign biliary strictures. Blumgart's Surgery of the Liver, Biliary Tract and Pancreas - 5th Edition, volume 1, ch 42A: 615-43.

2. Lubikowski J, Chmurowicz T, Post M, Jarosz K, Bialek A, Milkiewicz P, et al Liver transplantation as an ultimate step in the management of iatrogenic bile duct injury complicated by secondary biliary cirrhosis. Ann Transplant. 2012;17:38-44.

3. Barros F, Fernandes RA, Oliveira ME, Pacheco LF, Martinho JMSG. A influencia do tempo de referencia no tratamento das lesões iatrogênicas da via biliar. Ver. Col. Bras. Cir. 2010;37:407-12.

4. Ardiles V, McCormack L, Quiñonez E, Goldaracena N, Mattera J, Pekolj J, et al. Experience using liver transplantation for the treatment of severe bile duct injuries over 20 years in Argentina: results from a National Survey. HPB. 2011;13:544-50.

5. Lillemoe K, Ashley SW, Chen W. Repair of common bile duct injuries. UpToDate. 2016. [Accessed on 2016 May 27].

6. Halbert C, Altieri MS, Yang J, Meng Z, Chen H, Talamini M, et al. Long-term outcomes of patients with common bile duct injury following laparoscopic cholecystectomy. Surg Endosc. 2016:1-6.
7. Parrilla P, Robles R, Varo E, Jiménez C, Sánchez-Cabúz S, Pareja E. Liver transplantation for bile duct injury after open and laparoscopic cholecystectomy. BJS. 2014;101:63-8.

8. Barbier L, Souche R, Slim K, Ah-Soune P. Long-term consequences of bile duct injury after cholecystectomy. J Visc Surg, 2014;151:269-79.

9. Negi SS, Sakhuja P, Malhotra V, Chaudhary A. Factors predicting advanced hepatic fibrosis in patients with postcholecystectomy bile duct strictures. Arch Surg. 2004;139:299-303.

10. Loinaz C, González EM, Jiménez C, García I, Gómez R, González-Pinto I, et al. Long-term biliary complications after liver surgery leading to liver transplantation. World J. Surg. 2001;25:1260-3.

11. Addeo P, Saouli AC, Ellero B, Woehl-Jaegle ML, Oussoultzoglou E, Rosso E, et al. Liver transplantation for iatrogenic bile duct injuries sustained during cholecystectomy. Hepatol Int. 2013;7:910-5.

12. Coelho GR, Feitosa Neto BA, Teixeira CCG, Marinho, DS, Rangel MLM, Garcia JHP. Single-Center transfusion rate for 555 consecutive liver transplantations: impacto of two eras. Transplant Proc. 2013:45:3305-9. 